\title{
PENGARUH EKUITAS MEREK DAN WORD OF MOUTH TERHADAP KEPUTUSAN PEMBELIAN SMARTPHONE OPPO (SURVEI PADA MAHASISWA STIE SULTAN AGUNG SEMESTER VI TAHUN AKADEMIK 2016/2017)
}

\author{
Oleh: \\ Ganda Manurung \\ S1 Manajemen \\ Darwin Lie, Marisi Butarbutar, Ady Inrawan
}

Abstraksi

Hasil penelitian: 1. Ekuitas merek, word of mouth dan keputusan pembelian sudah baik. 2. Hasil analisis regresi adalah $\hat{\mathrm{Y}}=8,177+0,724 \mathrm{X}_{1}+0,255 \mathrm{X}_{2}$, artinya ekuitas merek dan word of mouth berpengaruh positif terhadap keputusan pembelian. 3. Hasil analisis korelasi diperoleh nilai $r=0,813$ terdapat hubungan yang kuat dan positif antara ekuitas merek dan word of mouth dengan keputusan pembelian. Keputusan pembelian dipengaruhi oleh ekuitas merek dan word of mouth sebesar 66,2\%. 4. Hipotesis penelitian $\mathrm{H}_{0}$ ditolak dan $\mathrm{H}_{a}$ diterima, artinya ekuitas merek dan word of mouth berpengaruh positif dan signifikan terhadap keputusan pembelian pada smartphone Oppo baik secara simultan maupun parsial.

Adapun saran dari penelitian ini adalah meningkatkan ekuitas merek, perlu dilakukan inovasi fitur yang canggih sesuai dengan keinginan konsumen yaitu fitur selfie dengan kualitas kamera depan yang sangat bagus serta resolusi kamera yang cukup besar demi medapatkan selfie yang berkualitas. Untuk mempertahankan word of mouth pada smartphone Oppo, maka penyebaran informasi atau promosi melalui iklan sebaiknya di jam prime time dengan konsep iklan yang lebih menarik agar pengguna produk smartphone Oppo semakin bertambah. Sedangkan untuk mempertahankan meningkatkan keputusan pembelian konsumenn, dengan melakukan inovasi dalam menghadirkan desain yang unik dan mengedepankan spesifikasi agar mendapatkan perhatian dari konsumen.

Kata kunci: Kualitas Produk, Harga, dan Kepuasan Konsumen.

\section{Abstraction}

The result of this research: 1. Brand equity, word of mouth and purchasing decisions already high. 2. The results of the regression analysis is $\hat{Y}=8,177+0,724 X_{1}+0,255 X_{2}$, means this research have positive between of the brand equity and word of mouth on consumer purchasing decisions. 3. The results of correlation analysis obtained by $\mathrm{r}=0,813$, it mean there is a high correlation and positive between the brand equity and word of mouth, to consumer purchasing. Purchasing decisions are influenced by the brand equity and word of mouth of $66.2 \%$. 4. The hypothesis of research $H_{0}$ is rejected and $H_{a}$ is accepted, it means that the brand equity and word of mouth positive and significant effect of the purchase on the Oppo smartphone either simultaneously or partial.

As for the suggestion of this research is to increase brand equity, the need for sophisticated feature innovations in accordance with the wishes of consumers selfie features with the quality front camera which is very nice as well as the resolution of the camera that is large enough for the sake of who were the selfie. To preserve the word of mouth on the Oppo smartphone, then spread information or promotion through advertising in prime time hours, preferably with a more interesting advertising concept that users increasingly Oppo smartphone products. Whereas, to maintain the increasing konsumenn purchasing decisions, by making innovations in presenting a unique design and specification put forward in order to get the attention of consumers.

Keywords: Product Quality, Price, and Consumer Satisfaction.

\section{A. Pendahuluan}

\section{Latar Belakang Masalah}

Perusahaan telekomunikasi seluler di Indonesia semakin pesat dan bersaing sehingga memberikan banyak manfaat untuk memudahkan manusia dalam mendapatkan informasi. Informasi yang di dapat bisa melalui smartphone. Smartphone sangat membantu akan kebutuhan manusia. Smartphone membantu manusia dalam melakukan aktivitasnya. Seperti berselancar di media social, belanja online, dan masih bayak lagi. Salah satu smartphone yang lagi tren sekarang ini adalah smartphone Oppo

Smartphone Oppo adalah penyedia layanan eletronik dan teknologi global yang membawakan perangkat elektronik seluler terbaru dan tercanggih di lebih dari 20 negara, termasuk Amerika Serikat, China, Australia, dan Negara-negara lain di Eropa, Asia Tenggara, Asia Selatan, Timur Tengah dan Afrika. Oppo berusaha memberikan pengalaman menggunakan ponsel terbaik melalui desain yang cermat dan teknologi yang cerdas.

Penulis memilih mahasiswa STIE Sultan Agung sebagai responden karena mahasiswa sekarang update dengan berita informasi, banyak menggunakan fitur selfie, dan ingin selalu eksis di media social merupakan hal yang dilihat oleh mahasiswa dalam memilih smartphone yang digunakannya. 
Berikut ini adalah gambaran keputusan pembelian konsumen pada Oppo smartphone (wawancara pra survei mahasiswa STIE Sultan Agung pengguna Oppo smartphone) sebagai berikut:

Tabel 1

Fenomena Keputusan Pembelian

Konsumen pada Smartphone OPPO

\begin{tabular}{|c|c|c|c|c|c|c|}
\hline $\begin{array}{l}\text { Dimens } \\
\quad \text { i }\end{array}$ & $\begin{array}{l}\mathbf{S} \\
\mathbf{S}\end{array}$ & $\mathbf{S}$ & KS & TS & $\begin{array}{c}\text { ST } \\
\text { S }\end{array}$ & $\begin{array}{c}\text { TO } \\
\text { TA } \\
\text { L }\end{array}$ \\
\hline $\begin{array}{l}\text { Pengenal } \\
\text { an } \\
\text { Masalah }\end{array}$ & $\begin{array}{l}30 \\
\%\end{array}$ & $\begin{array}{l}50 \\
\%\end{array}$ & $\begin{array}{l}15 \\
\%\end{array}$ & $5 \%$ & $0 \%$ & $\begin{array}{c}100 \\
\%\end{array}$ \\
\hline $\begin{array}{l}\text { Pencaria } \\
\mathrm{n} \\
\text { Informas } \\
\mathrm{i}\end{array}$ & $\begin{array}{l}30 \\
\%\end{array}$ & $\begin{array}{l}45 \\
\%\end{array}$ & $\begin{array}{l}20 \\
\%\end{array}$ & $5 \%$ & $0 \%$ & $\begin{array}{c}100 \\
\%\end{array}$ \\
\hline $\begin{array}{l}\text { Evaluasi } \\
\text { Alternati } \\
\mathrm{f}\end{array}$ & $\begin{array}{l}30 \\
\%\end{array}$ & $\begin{array}{l}55 \\
\%\end{array}$ & $\begin{array}{l}10 \\
\%\end{array}$ & $5 \%$ & $0 \%$ & $\begin{array}{c}100 \\
\%\end{array}$ \\
\hline $\begin{array}{l}\text { Keputusa } \\
\mathrm{n} \\
\text { Pembelia } \\
\mathrm{n} \\
\text { Konsume } \\
\mathrm{n}\end{array}$ & $\begin{array}{l}30 \\
\%\end{array}$ & $\begin{array}{l}50 \\
\%\end{array}$ & $\begin{array}{l}15 \\
\%\end{array}$ & $5 \%$ & $0 \%$ & $\begin{array}{c}100 \\
\%\end{array}$ \\
\hline $\begin{array}{l}\text { Perilaku } \\
\text { Setelah } \\
\text { Pembelia } \\
\mathrm{n}\end{array}$ & $\begin{array}{l}30 \\
\%\end{array}$ & $\begin{array}{l}50 \\
\%\end{array}$ & $\begin{array}{l}15 \\
\%\end{array}$ & $5 \%$ & $0 \%$ & $\begin{array}{c}100 \\
\%\end{array}$ \\
\hline $\begin{array}{c}\text { Rata- } \\
\text { rata }\end{array}$ & $\begin{array}{l}30 \\
\%\end{array}$ & $\begin{array}{l}50 \\
\%\end{array}$ & $\begin{array}{l}15 \\
\%\end{array}$ & $5 \%$ & $0 \%$ & $\begin{array}{c}100 \\
\%\end{array}$ \\
\hline
\end{tabular}

Sumber: hasil wawancara pra survei Mahasiswa STIE Sultan Agung pengguna Oppo smartphone (Mei 2017).

Dari tabel 1 terlihat bahwa keputusan pembelian Mahasiswa STIE Sultan Agung sudah baik maka perlu dipertahankan dan ditingkatkan lagi. Fenomena pengenalan masalah terdapat $15 \%$. Hal ini agar konsumen lebih cermat dalam memilih produk smartphone yang sesuai dengan masalah kebutuhannya. Selanjutnya $20 \%$ dalam pencarian informasi. Hal ini fitur-fitur canggih dan harga yang murah juga seringkali menjadi daya tarik bagi konsumen.

Kemudian $10 \%$ dalam evaluasi alternatif. Hal ini smartphone Oppo melakukan inovasi produk yang lebih menarik. Ini dilakukan agar konsumen memiliki pilihan yang semakin banyak dalam membeli produk yang dikeluarkan. Pada keputusan pembelian konsumen 15\%. Hal ini dilakukan untuk menyediakan promosi penjualan seperti mengadakan kuis dengan pemberian hadiah dan potongan harga. Perilaku setelah pembelian sebesar $15 \%$. Hal ini untuk meningkatkan niat beli masyarakat, Oppo smartphone meningkatkan akan pelayanan dan desain produk yang diberikan saat pembelian maupun perilaku setelah pembelian.
Salah satu faktor yang dapat meningkatkan keputusan pembelian suatu produk adalah melalui ekuitas merek. Ekuitas merek merupakan nilai suatu merek berdasarkan seberapa kuat nilai merek tersebut yang memiliki peranan kesadaran merek, asosiasi merek, persepsi kualitas dan loyalitas merek. Hal ini dapat dilihat dari fenomena kesadaran merek untuk mengenali merek produk. Karena smartphone Oppo selalu berupaya mempertahankan kesadaran merek pada konsumen.

Pada fenomena asosiasi merek, smartphone Oppo mempunyai teknologi yang cerdas seperti fitur yang canggih dan produk yang berkualitas. Saat ini selfie sedang disukai banyak orang. Hal ini Oppo mengeluarkan Oppo camera phone yang dikhususkan buat orang-orang yang menyukai selfie dengan kualitas kamera terbaik. Pada fenomena loyalitas merek, Oppo smartphone baru-baru ini meraih penghargaan sebagai merek smartphone terbaik di CES (Consumer Electronic Show) tahun 2017 di Amerika Serikat. Ini menunjukkan loyalitas pengguna Oppo cukup tinggi terhadap pemakaian produk smartphone Oppo.

Selain ekuitas merek faktor lain yang mempengaruhi keputusan pembelian adalah word of mouth. Word of mouth merupakan komunikasi yang berkelanjutan dari satu pihak ke pihak lain atau dari konsumen satu ke konsumen lainnya. Word of mouth memiliki dimensi talkers, topics, tools, taking part, dan tracking. Fenomena talkers dalam hal ini konsumen harus memperhatikan informasi dan advise dari talkers atau pembicara yang diperoleh konsumen melalui orang-orang terdekat tentang produk. Fenomena topics dalam hal ini perusahaan Oppo harus memikirkan topik-topik yang bisa menjadi pembicaraan hangat ditengah masyarakat. Seperti pengenalan jenis-jenis produk yang menarik dan memperkenalkan fitur-fitur baru kepada konsumen.

Pada fenomena tools dalam hal ini konsumen mendapatkan informasi tentang produk melalui website resmi, brosur dan iklan televisi maupun tulisan konsumen melalui media sosial. Sehingga sebelum membeli smartphone Oppo konsumen sudah mengetahui jenis produk apa yang dibeli.

Ekuitas merek yang mumpuni serta word of mout yang selalu dipertahankan akan meningkatkan keputusan pembelian konsumen.

\section{Rumusan Masalah}

a. Bagaimana gambaran ekuitas merek, word of mouth, dan keputusan pembelian pada smartphone Oppo.

b. Bagaimana pengaruh ekuitas merek, dan word of mouth terhadap keputusan pembelian pada smartphone Oppo baik secara simultan maupun parsial.

\section{Tujuan Penelitian}

a. Untuk mengetahui gambaran ekuitas merek, word of mouth, dan keputusan pembelian pada smartphone Oppo. 
b. Untuk mengetahui pengaruh ekuitas merek dan word of mouth terhadap keputusan pembelian pada smartphone Oppo baik secara simultan maupun parsial.

\section{Metode Penelitian}

Objek penelitian adalah STIE Sultan Agung Pematangsiantar yang terletak di Jalan Surabaya No. 19 Pematangsiantar - 21118 Sumatera Utara. Populasi adalah mahasiswa STIE Sultan Agung semester VI tahun akademik 2016/2017 yang berjumlah 399 orang. Dengan menggunakan purposive sampling yaitu metode dimana dalam menentukan pemilihan sampel telah memenuhi kriteria yang ditentukan oleh peneliti yaitu yang menggunakan smartphone Oppo. Dari jumlah tersebut diperoleh sampel penelitian yang memenuhi kriteria sebanyak 52 mahasiswa.

Desain penelitian adalah Penelitian Kepustakaan (Library Research) dan Penelitian Lapangan (Field Research). Teknik pengumpulan data berupa Kuesioner, Wawancara dan Dokumentasi. Jenis data yang adalah jenis data kualitatif dan data kuantitatif. Hasil data yang diperoleh dari lapangan akan dianalisis secara deskriptif baik bersifat kualitatif dan kuantitatif.

\section{B. LANDASAN TEORI}

\section{Manajemen Pemasaran}

Menurut Kotler dan Gary (2008:10), manajemen pemasaran adalah seni dan ilmu memilih target pasar dan membangun hubungan yang menguntungkan dengan target pasar. Sedangkan menurut Kotler dan Kevin (2009:6), manajemen pemasaran didefinisikan sebagai ilmu dan seni memilih pasar sasaran kemudian mendapatkan, menjaga, dan menumbuhkan pelanggan dengan menciptakan, menyerahkan, dan mengkomunikasikan nilai pelanggan yang unggul. Lalu menurut Lupiyoadi dan Hamdani (2006:70), manajemen pemasaran adalah alat bagi pemasar yang terdiri atas berbagai unsur suatu program pemasaran yang perlu dipertimbangkan agar implementasi strategi pemasaran dan positioning yang diterapkan dapat berjalan dengan sukses. Berdasarkan uraian teori di atas, maka dapat disimpulkan bahwa manajemen pemasaran adalah ilmu dan seni dalam menciptakan, membangun, memelihara, dan mengkomunikasikan nilai pelanggan, merencanakan, mempromosikan dan menyalurkan barang dan jasa untuk mencapai tujuan perusahaan.

\section{Ekuitas Merek}

Menurut Kotler dan Gary (2008:282) ekuitas merek adalah pengaruh diferensial positif bahwa jika pelanggan mengenal merek, pelanggan akan merespon produk atau jasa. Menurut Aaker dalam Tijptono (2011:96), ekuitas merek adalah serangkaian aset dan kewajiban (liabilities) merek yang terkait dengan sebuah merek, nama, dan simbolnya, yang mampu menambah atau mengurangi nilai yang diberikan sebuah produk atau jasa kepada perusahaan dan/atau pelanggan perusahaan tersebut. Sedangkan menurut Kotler dan Kevin (2008:334), ekuitas merek adalah nilai tambah yang diberikan pada produk dan jasa. Nilai ini bisa dicerminkan dalam cara konsumen berpikir, merasa, dan bertindak terhadap merek, harga, pangsa pasar, dan profitabilitas yang dimiliki perusahaan.

Dari definisi yang dipaparkan oleh beberapa ahli di atas dapat disimpulkan bahwa ekuitas merek merupakan serangkaian aset dan kewajiban merek yang terkait dengan sebuah merek, nama, dan simbolnya, yang memungkinkan suatu merek mendapatkan kekuatan, daya tahan, dan keunggulan yang dapat membedakan dengan merek pesaing.

Menurut Hasan (2013:226), ada beberapa elemen pembentuk ekuitas merek yang terdiri dari: peranan kesadaran merek, asosiasi merek, persepsi kualitas dan loyalitas merek.

\section{Word of Mouth}

Menurut Menurut Kotler dan Gary (2008:128) word of mouth adalah saluran komunikasi secara pribadi dimana satu atau lebih orang berkomunikasi secara langsung satu sama lain. Mereka bisa berkomunikasi melalui tatap muka, telepon, melalui pos atau e-mail, atau bahkan melalui percakapan internet. Menurut Szabo dalam Hasan (2010:32) word of mouth adalah upaya memberikan alasan agar orang berbicara tentang merek, produk, maupun jasa dan membuat berlangsungnya pembicaraan itu lebih mudah. Sedangkan menurut Mowen dan Minor (2002:180) word of mouth didefinisikan pertukaran perkataan, pemikiran, atau ide-ide di antara dua konsumen atau lebih, dengan tidak memberikan sumber pemasaran.

Berdasarkan pendapat para ahli di atas, penulis menyimpulkan bahwa word of mouth adalah upaya memberikan alasan yang disampaikan oleh orang lain tentang ide-ide, merek produk maupun jasa dan membuat pembicaraan itu lebih mudah.

Menurut Sernovitz (2009:31), menyebutkan lima dimensi yang dibutuhkan dalam menyebarkan word of mouth: dimensi talkers, topics, tools, taking part, dan tracking

\section{Keputusan Pembelian}

Menurut Setiadi (2010:332), keputusan pembelian merupakan proses pengintegrasian yang menggabungkan pengetahuan untuk mengevaluasi dua tindakan alternatif atau lebih dan memilih salah satu di antaranya. Menurut Kotler dan Kevin (2009:188), keputusan pembelian adalah proses dimana konsumen membentuk preferensi antar merek dalam kumpulan pilihan atau konsumen mungkin juga membentuk maksud untuk membeli merek yang paling disukai. Sedangkan menurut Kotler dan Gary (2008:181), keputusan pembelian didefinisikan sebagai membeli diantara beberapa merek yang paling disukai, tetapi dua faktor bisa berada antara niat pembelian dan keputusan pembelian. Menurut Kotler dan Kevin (2009:184), tahapan proses pengambilan keputusan konsumen adalah sebagai berikut: pengenalan masalah, 
pencarian informasi, evaluasi alternatif, keputusan pembelian konsumen dan perilaku setelah pembelian.

Berdasarkan pendapat beberapa ahli di atas, dapat disimpulkan bahwa keputusan pembelian keputusan pembelian adalah proses pengintegrasian dimana konsumen membentuk preferensi antar merek dalam kumpulan pilihan atau konsumen mungkin juga membentuk maksud untuk membeli merek yang paling disukai dan membentuk keputusan pembelian.

\section{PEMBAHASAN}

\section{Analisis}

\section{a. Deskriptif Kualitatif}

Analisis deskriptif dimaksudkan untuk mendapatkan gambaran atau deskripsi mengenai tanggapan dari konsumen mengenai pengaruh ekuitas merek dan word of mouth terhadap keputusan pembelian pada Oppo smartphone (survei pada mahasiswa STIE Sultan Agung pengguna Oppo smartphone). Setelah pengujian data maka langkah selanjutnya melakukan pengkajian kualitatif sebagai gambaran fenomena dari variabel penelitian pada saat sekarang ini.

Adapun penetapan kriteria nilai rata-rata jawaban dari responden tersebut dimasukkan kedalam kelas-kelas interval dimana penentuan intervalnya memakai rumus sebagai berikut: Interval Kelas $=$ Nilai Tertinggi - Nilai Terendah

$$
\begin{aligned}
& =\frac{5-1}{5} \\
& =\frac{4}{5} \\
& =0,80
\end{aligned}
$$

Dari rumus diatas dapat diperoleh interval kelas 0,80 sehingga berlaku ketentuan kategori dengan hasil

\begin{tabular}{|c|c|c|c|}
\hline \multirow{3}{*}{$\begin{array}{c}\text { Nilai } \\
\text { Interval }\end{array}$} & \multirow{2}{*}{\multicolumn{3}{|c|}{ Kategori }} \\
\hline & & & \\
\hline & $\begin{array}{c}\text { Ekuitas } \\
\text { Merek }\end{array}$ & $\begin{array}{l}\text { Word of } \\
\text { Mouth }\end{array}$ & $\begin{array}{l}\text { Keputusan } \\
\text { Pembelian }\end{array}$ \\
\hline \multirow{3}{*}{$\begin{array}{c}1,00- \\
1,80\end{array}$} & Sangat & Sangat & Sangat \\
\hline & Tidak & Tidak & Tidak \\
\hline & Setuju & Setuju & Setuju \\
\hline \multirow{2}{*}{$\begin{array}{c}1,81- \\
2,60\end{array}$} & Tidak & Tidak & Tidak \\
\hline & Setuju & Setuju & Setuju \\
\hline \multirow{2}{*}{$\begin{array}{c}2,61- \\
3,40\end{array}$} & Kurang & Kurang & Kurang \\
\hline & Setuju & Setuju & Setuju \\
\hline $\begin{array}{c}3,41- \\
4,20\end{array}$ & Setuju & Setuju & Setuju \\
\hline \multirow{2}{*}{$\begin{array}{c}4,21- \\
5,00\end{array}$} & Sangat & Sangat & \\
\hline & Setuju & Setuju & Setuju \\
\hline
\end{tabular}
berikut:

Tabel 2

Sumber : hasil pengolahan data kuesioner (2017)

\section{1) Gambaran Ekuitas Merek produk Oppo Smartphone}

Dari hasil analisa, dapat dilihat bahwa untuk dimensi kesadaran merek pada indikator merek produk memiliki nilai rata-rata 3,96 dengan kriteria jawaban setuju, disebabkan gencarnya iklan yang dilakukan perusahaan Oppo, sehingga konsumen mudah mengingat dan mengenali produk smartphone Oppo. Pada indikator variasi merek memiliki nilai rata-rata 4,15 dengan kriteria jawaban setuju. Hal ini disebabkan karena perusahaan Oppo memperhatikan apa yang menjadi kebutuhan dari konsumen sehingga menyediakan aneka produk smartphone dengan harga yang kompetitif. Pada indikator ciri khas memiliki nilai rata-rata 4,02 dengan kriteria jawaban setuju. Hal ini disebabkan karena perusahaan tetap konsisten untuk mempertahankan produk yang memiliki kualitas yang baik dan harga yang bersaing.

Dimensi asosiasi merek pada indikator inovasi produk memiliki nilai rata-rata 3,96 dengan kriteria jawaban setuju, disebabkan smartphone merek Oppo mempunyai kamera super canggih seperti Oppo N1 yang bisa diputar ke depan dan ke belakang atau 360 derajad. Artinya, Oppo tidak lagi menyediakan dual kamera, sehingga Oppo menjadi smartphone pertama yang melakukan inovasi seperti ini. Pada indikator fitur memiliki nilai rata-rata 3,44 dengan kriteria jawaban setuju. Hal ini disebabkan produk smartphone Oppo memiliki fitur yang canggih menjadikan alasan konsumen untuk melakukan pembelian smartphone Oppo. Pada indikator manfaat memiliki nilai rata-rata 4,25 dengan kriteria jawaban sangat setuju. Hal ini disebabkan mahasiswa dalam pencarian informasi dapat menyelesaikan tugas-tugas kampus menggunakan smartphone yang memberikan manfaat sesuai kebutuhan mahasiswa.

Selanjutnya dimensi persepsi kualitas pada indikator kinerja produk memiliki nilai rata-rata 4,08 dengan kriteria jawaban setuju, disebabkan smartphone Oppo adalah smartphone dengan fiturfitur yang mudah digunakan oleh konsumen karena konsumen saat membeli produk sudah diajarkan cara pengoperasian produk. Pada indikator keunggulan produk memiliki nilai rata-rata 3,92 dengan kriteria jawaban setuju. Hal ini disebabkan smartphone Oppo memiliki keunggulan dengan cara memposisikan dirinya sebagai smartphone tertipis di dunia yaitu Oppo R5 mengalahkan smartphone lain. Pada indikator kualitas produk memiliki nilai rata-rata 4,04 dengan kriteria jawaban setuju. Hal ini disebabkan karena setiap merek produk smartphone Oppo yang dibeli konsumen merupakan produk yang memiliki kualitas yang terbaik dan terjamin di mata konsumen.

Dimensi loyalitas merek pada indikator komitmen pelanggan memiliki nilai rata-rata 3,71 dengan kriteria jawaban setuju. Hal ini disebabkan karena konsumen merasakan kepuasan terhadap pemakaian merek produk sehingga meningkatkan komitmen untuk melakukan pembelian secara berulang-ulang. Pada indikator pilihan memiliki nilai rata-rata 3,73 dengan kriteria jawaban setuju, disebabkan karena produk Oppo yang ditawarkan perusahaan merupakan merek dengan kualitas yang bagus serta penjualannya yang laris di pasaran. Pada indikator rekomendasi memiliki nilai rata-rata 3,87 dengan kriteria jawaban setuju. Hal ini disebabkan 
karena konsumen puas dengan kamera depan dan belakang Oppo smartphone yang bebas untuk melakukan selfie.

Secara keseluruhan dapat dilihat bahwa nilai rata-rata untuk variabel ekuitas merek berdasarkan jawaban responden adalah 3,92 dengan kriteria jawaban setuju. Nilai rata-rata tertinggi sebesar 4,25 dengan kriteria jawaban sangat setuju diperoleh dimensi asosiasi merek pada indikator manfaat smartphone yang sesuai dengan kebutuhan mahasiswa. Sedangkan nilai rata-rata terendah sebesar 3,44 dengan kriteria jawaban setuju diperoleh dimensi asosiasi merek pada indikator fitur-fitur smartphone Oppo yang canggih dan unik.

\section{2) Gambaran Word of Mouth produk Oppo Smartphone}

Dari hasil analisa, dapat dilihat bahwa untuk dimensi talkers pada indikator informasi dari orang terdekat memiliki nilai rata-rata 3,88 dengan kriteria jawaban setuju. Hal ini disebabkan karena rata-rata konsumen memperoleh informasi tentang produk Oppo dari cerita orang-orang terdekat yang sebelumnya telah melakukan transaksi pembelian. Pada indikator kepercayaan memiliki nilai rata-rata 3,77 dengan kriteria jawaban setuju. Hal ini disebabkan karena word of mouth yang meyakinkan dan memiliki kepercayaan yang kuat akan produk lebih disukai oleh konsumen dibandingkan dengan promosi iklan.

Pada indikator pengaruh seseorang memiliki nilai rata-rata 3,71 dengan kriteria setuju. Hal ini disebabkan karena konsumen mengetahui mengenai produk smartphone Oppo dari orang-orang yang dapat dipercaya. Pada indikator pengetahuan memiliki nilai rata-rata 3,98 dengan kriteria setuju. Hal ini disebabkan talkers atau pembicara yang memberikan informasi tentang produk kepada konsumen memiliki tingkat pengetahuan yang baik.

Selanjutnya dimensi topics pada indikator keunikan produk memiliki nilai rata-rata 3,94 dengan kriteria jawaban setuju. Hal ini dikarenakan smartphone Oppo memiliki jenis produk yang unik salah satunya Oppo F1s ini memiliki desain yang cermat dengan lengkungan disetiap performanya serta ketipisan mencapai $7.38 \mathrm{~mm}$ membuat smarthphone ini pas di tangan. Pada indikator pelayanan memiliki nilai rata-rata 3,96 dengan kriteria jawaban setuju. Hal ini Oppo memberikan pelayanan khusus bagi pengguna smartphone Oppo, dengan cara memperoleh diskon untuk penggantian sparepart seperti baterai dan casing, yang dapat diperoleh dari service center Oppo.

Pada indikator lokasi memiliki nilai rata-rata 4,12 dengan kriteria jawaban setuju. Hal ini disebabkan perusahaan memberikan kemudahan kepada konsumen dengan lokasi yang mudah di jangkau terletak di pusat kota Siantar. Pada indikator kegunaan produk memiliki nilai rata-rata 4,00 dengan kriteria jawaban setuju. Hal ini disebabkan karena konsumen merasakan manfaat produk yang sesuai dengan kebutuhan mahasiswa untuk menyelesaikan tugas-tugas atau mencari informasi.
Pada indikator jenis-jenis produk memiliki nilai ratarata 4,06 dengan kriteria jawaban setuju. Hal ini disebabkan konsumen bebas memilih produk yang diinginkan karena smartphone Oppo memiliki jenisjenis produk yang menarik dengan harga yang mampu bersaing dengan produk lain.

Dimensi tools pada indikator brosur memiliki nilai rata-rata 3,35 dengan kriteria jawaban kurang setuju. Hal ini disebabkan informasi yang dilakukan Oppo melalui pembagian brosur kurang diketahui konsumen. Brosur yang dibagikan kepada konsumen harus tepat sasaran dan menginformasikan secara detail mengenai spesifikasi smartphone Oppo sehingga dapat menyampaikan kepada masyarakat mengenai tipe terbaru dari smartphone Oppo. Pada indikator iklan memiliki nilai rata-rata 3,29 dengan kriteria jawaban kurang setuju. Hal ini disebabkan informasi yang di dapat konsumen tidak semua dari iklan, sehingga Oppo harus melakukan pemasangan iklan di jam prime time, agar banyak orang mengetahui produk smartphone Oppo. Pada indikator media sosial memiliki nilai rata-rata 3,63 dengan kriteria jawaban setuju. Hal ini disebabkan karena memudahkan konsumen menceritakan informasi produk berupa opini tentang produk smartphone Oppo melalui media sosial.

Dimensi taking part pada indikator diskon memiliki nilai rata-rata 3,73 dengan kriteria jawaban setuju. Hal ini disebabkan perusahaan memberikan diskon atau potongan harga pada akhir tahun terhadap beberapa tipe smartphone sehingga konsumen mendapatkan smartphone Oppo dengan harga yang terjangkau. Pada indikator ketanggapan penanganan memiliki nilai rata-rata 3,77 dengan kriteria jawaban setuju. Hal ini disebabkan pihak Oppo dapat menangani setiap pertanyaan tentang produk dengan baik kepada konsumen. Pada indikator penjelasan detail memiliki nilai rata-rata 3,81 dengan kriteria jawaban setuju. Hal ini disebabkan karena Oppo dapat menangani dalam menjelaskan produk secara detail kepada konsumen melaui gerai dan toko yang disediakan oleh Oppo.

Dimensi tracking pada indikator tersedianya media sosial memiliki nilai rata-rata 4,00 dengan kriteria jawaban setuju. Hal ini karena perusahaan menyediakan media sosial seperti website resmi Oppo dan email Oppo yaitu service.id@oppo.com sebagai tempat kritik dan saran konsumen. Pada indikator tersedianya service center memiliki nilai rata-rata 3,65 dengan kriteria jawaban setuju. Hal ini disebabkan karena perusahaan menyediakan Pick Up \& Delivery Service, artinya layanan penjemputan smartphone Oppo yang mengalami masalah kerusakan dengan cara menjemput produk dari rumah konsumen untuk diperbaiki ke Oppo service center yang ada di Jalan Thamrin (Soa Sio) No 22G Pematangsiantar. Pada indikator customer service memiliki nilai rata-rata 3,79 dengan kriteria setuju. Hal ini karena tersedianya customer service dengan nomor yang bisa dihubungi 0018038516776 bebas biaya sehingga dapat menyampaikan kritik dan saran konsumen. 
Secara keseluruhan dapat dilihat bahwa nilai rata-rata untuk variabel word of mouth berdasarkan jawaban responden adalah 3,80 dengan kriteria jawaban setuju. Nilai rata-rata tertinggi sebesar 4,12 dengan kriteria jawaban setuju diperoleh dimensi topics pada indikator lokasi yang mudah dijangkau oleh konsumen. Sedangkan nilai rata-rata terendah sebesar 3,29 dengan kriteria jawaban kurang setuju diperoleh dimensi tools pada indikator iklan yang menarik dilakukan pihak Oppo.

\section{3) Gambaran Keputusan Pembelian produk Oppo Smartphone}

Dari hasil analisa, dapat dilihat bahwa untuk dimensi pengenalan masalah pada indikator kebutuhan konsumen smartphone Oppo memiliki nilai rata-rata 3,96 dengan kriteria jawaban setuju. Hal ini terjadi karena perusahaan memperhatikan apa yang menjadi kebutuhan dari konsumen sehingga menyediakan jenis-jenis produk yang berkualitas Pada indikator keinginan konsumen memiliki nilai rata-rata 3,98 dengan kriteria jawaban setuju. Hal ini disebabkan perusahaan selalu memperhatikan apa yang menjadi keinginan konsumen dengan menyediakan merek produk yang disediakan smartphone Oppo. Pada indikator kemantapan produk memiliki nilai rata-rata 4,09 dengan kriteria jawaban setuju. Hal ini disebabkan Oppo memberikan kemantapan produk bagi konsumen yang memberikan manfaat dalam kemudahan berkomunikasi.

Dimensi pencarian informasi pada indikator informasi memiliki nilai rata-rata 4,19 dengan kriteria jawaban setuju. Hal ini disebabkan karena rata-rata konsumen yang datang ke perusahaan direkomendasikan oleh kerabat mereka yang sebelumnya telah melakukan transaksi pembelian. Pada indikator karakteristik produk memiliki nilai rata-rata 4,15 dengan kriteria jawaban setuju. Hal ini disebabkan karena karakteristik dari produk yang dihasilkan smartphone Oppo telah sesuai dengan persepsi konsumen mengenai produk yang diinginkan. Pada indikator keputusan konsumen memiliki nilai rata-rata 4,06 dengan kriteria jawaban setuju. Hal ini disebabkan sebelum konsumen memutuskan untuk membeli smartphone Oppo, konsumen terlebih dahulu melihat spesifikasi produk dan membandingkannya dengan smartphone merek lain.

Dimensi evaluasi alternatif pada indikator evaluasi produk memiliki nilai rata-rata 3,96 dengan kriteria jawaban setuju. Hal ini disebabkan perusahaan berusaha menerapkan kebijakan harga yang berkualitas sesuai jenis produknya masingmasing sehingga konsumen merasakan evaluasi produk smartphone Oppo.

Pada indikator desain yang cermat memiliki nilai rata-rata 3,40 dengan kriteria jawaban kurang setuju. Hal ini disebabkan karena banyak konsumen yang mengatakan bahwa produk keluaran China mudah rusak dan masih meragukan kualitas akan desain dari smartphone Oppo. Baru-baru ini Oppo membuktikan dan berhasil mendapatkan penghargaan sebagai merek smartphone terbaik di CES (Consumer Electronic Show) tahun 2017 di Amerika Serikat, merupakan prestasi yang membanggakan sehingga kedepannya Oppo memiliki desain yang lebih cermat dan berinovasi dalam hal desain produk. Pada indikator pilihan alternatif memiliki nilai rata-rata 4,02 dengan kriteria jawaban setuju. Hal ini disebabkan karena produk yang ditawarkan smartphone Oppo telah sesuai dengan pertimbangan alternatif konsumen.

Dimensi keputusan pembelian konsumen pada indikator promosi memiliki nilai rata-rata 3,96 dengan kriteria jawaban setuju. Hal ini disebabkan perusahaan menerapkan kebijakan promosi demi keuntungan konsumen, seperti mengadakan kuis dengan pemberian hadiah dan potongan harga yang diberikan smartphone Oppo bagi konsumen. Pada indikator variasi harga memiliki nilai rata-rata 4,08 dengan kriteria jawaban setuju. Hal ini disebabkan karena konsumen diberikan kebebasan untuk memilih variasi harga yang ditawarkan smartphone Oppo.

Pada indikator pelayanan yang diberikan memiliki nilai rata-rata 4,25 dengan kriteria jawaban sangat setuju. Hal ini disebabkan karena persaingan semakin ketat, Oppo meningkatkan pelayanan dalam hal penjualan yaitu Oppo Service Center sebagai tempat perbaikan atau reparasi jika smartphone Oppo mengalami kerusakan, dengan teknisi mumpuni dan konsumen dapat melihat langsung proses perbaikan smartphone yang dimilikinya, sehingga konsumen menjadi terpuaskan karena pelayanan yang diberikan oleh Oppo.

Dimensi perilaku setelah pembelian pada indikator pembelian ulang memiliki nilai rata-rata 3,75 dengan kriteria jawaban setuju. Hal ini disebabkan karena konsumen melakukan pembelian pada produk smartphone Oppo yang memiliki kualitas terjamin dan laris dipasaran. Pada indikator varian terbaru memiliki nilai rata-rata 3,69 dengan kriteria jawaban setuju. Hal ini disebabkan karena konsumen up date soal varian terbaru Oppo dan melakukan pembelian secara berulang-ulang. Pada indikator kepuasan memiliki nilai rata-rata 4,17 dengan kriteria jawaban setuju. Hal ini disebabkan konsumen merasa puas setelah menggunakan produk-produk smartphone Oppo.

Secara keseluruhan dapat dilihat bahwa nilai rata-rata untuk variabel keputusan pembelian berdasarkan jawaban responden adalah 3,98 dengan kriteria jawaban setuju. Nilai rata-rata tertinggi sebesar 4,25 dengan kriteria jawaban sangat setuju diperoleh dimensi keputusan pembelian konsumen pada indikator pelayanan yang memuaskan konsumen karena mempengaruhi keputusan pembelian smartphone Oppo. Sedangkan nilai ratarata terendah sebesar 3,40 dengan kriteria jawaban kurang setuju diperoleh dimensi evaluasi alternatif pada indikator desain smartphone Oppo memiliki desain yang unik.

\section{b. Deskriptif Kuantitatif}

1) Regresi Linear Berganda 
Penelitian ini memiliki tujuan untuk menganalisis pengaruh ekuitas merek dan word of mouth terhadap keputusan pembelian. Analisis data dalam penelitian ini menggunakan analisis regresi linier berganda. Analisis regresi linier berganda digunakan untuk mengetahui pengaruh variabel bebas $(\mathrm{X})$ dan variabel terikat $(\mathrm{Y})$, dimana $\mathrm{X}$ adalah ekuitas merek, word of mouth, dan $\mathrm{Y}$ adalah keputusan pembelian konsumen. Maka dilakukan perhitungan menggunakan program aplikasi SPSS versi 21 dengan hasil hitung regresi sebagai berikut:

Tabel 3

Hasil Regresi Linear Berganda Coefficients $^{\mathrm{a}}$

\begin{tabular}{|c|c|c|c|c|}
\hline \multirow[b]{2}{*}{ Model } & & \multicolumn{2}{|c|}{$\begin{array}{c}\text { Unstandardized } \\
\text { Coefficients }\end{array}$} & $\begin{array}{c}\text { Standard } \\
\text { ized } \\
\text { Coefficie } \\
\text { nts }\end{array}$ \\
\hline & & B & Std. Error & Beta \\
\hline & $\begin{array}{l}\text { (Constan } \\
t)\end{array}$ & 8.177 & 5.382 & \\
\hline & $\begin{array}{l}\text { Ekuitas } \\
\text { Merek }\end{array}$ & .724 & .133 & .590 \\
\hline & $\begin{array}{l}\text { Word of } \\
\text { Mouth }\end{array}$ & .255 & .093 & .298 \\
\hline
\end{tabular}

a. Dependent Variable: Keputusan Pembelian

Sumber: hasil pengolahan data dengan SPSS versi 20

Dari tabel 3 di atas, dapat diperoleh persamaan regresi adalah sebagai berikut: $\hat{Y}=8,177+0,724 X_{1}$ $+0,255 \mathrm{X}_{2}$, artinya terdapat pengaruh yang positif antara ekuitas merek dan word of mouth terhadap keputusan pembelian konsumen smartphone Oppo pada mahasiswa STIE Sultan Agung.

\section{2) Koefisien Korelasi dan Koefisien Determinasi}

Hasil koefisien korelasi dan koefisien determinasi dapat dilihat pada tabel berikut:

Tabel 4

Hasil Koefisien Korelasi dan Koefisien Determinasi

\begin{tabular}{|c|c|c|c|c|}
\hline Model & $\mathbf{R}$ & $\begin{array}{c}\mathbf{R} \\
\text { Squar } \\
e\end{array}$ & $\begin{array}{l}\text { Adjusted } \\
R \text { Square }\end{array}$ & $\begin{array}{l}\text { Std. Error of } \\
\text { the Estimate }\end{array}$ \\
\hline 1 & $.813^{a}$ & .662 & .648 & 4.897 \\
\hline
\end{tabular}

a. Predictors: (Constant), Word of Mouth, Ekuitas Merek,

b. Dependent Variable: Keputusan Pembelian

Sumber: hasil pengolahan data dengan SPSS versi 20

Berdasarkan tabel 4 diperoleh nilai $r$ sebesar

0,813 , yang artinya terdapat hubungan yang sangat

kuat dan positif antara ekuitas merek dan word of mouth dengan keputusan pembelian smartphone Oppo pada mahasiswa STIE Sultan Agung, sesuai dengan kriteria koefisien korelasi pada tabel 8 . Kemudian diperoleh nilai koefisien determinasi ( $\mathrm{R}$ Square $)=0,662$, artinya baik tidaknya keputusan pembelian sebesar $66,2 \%$ dipengaruhi oleh ekuitas merek dan word of mouth, sedangkan selebihnya sebesar 33,8\% dipengaruhi oleh variabel-variabel lain yang tidak dijelaskan pada penelitian ini seperti iklan, fitur, harga, promosi, kualitas pelayanan dan sebagainya..

\section{3) Uji Hipotesis}

\section{a) Uji Simultan (Uji F)}

Pengujian ini dilakukan secara simultan, yaitu dilakukan untuk menentukan diterima atau ditolaknya hipotesis. Pengujian hipotesis dilakukan untuk mengetahui apakah variabel ekuitas merek dan word of mouth yang diuji berpengaruh terhadap keputusan pembelian. Jika $F_{\text {hitung }}>F_{\text {tabel }}$ atau signifikansi $\leq 0,05$, maka $\mathrm{H}_{0}$ ditolak.

Untuk menghasilkan suatu kesimpulan yang valid, maka harus dilakukan uji hipotesis dengan menggunakan program SPSS versi 21.

Tabel 5

Hasil Uji Simultan (Uji F)

ANOVA $^{\mathrm{a}}$

\begin{tabular}{|l|r|r|c|c|r|}
\hline Model & $\begin{array}{c}\text { Sum of } \\
\text { Squares }\end{array}$ & df & $\begin{array}{c}\text { Mean } \\
\text { Square }\end{array}$ & F & Sig. \\
\hline Regressio & 2297.13 & 2 & 1148.57 & $\mathbf{4 7 . 8 9 4}$ & $\mathbf{. 0 0 0}$ \\
$n$ & 9 & 0 & & $\mathbf{b}$ \\
1 Residual & 1175.09 & 49 & 23.981 & & \\
2 & & & & \\
Total & 3472.23 & 51 & & & \\
1 & & & & \\
\hline
\end{tabular}

a. Dependent Variable: Keputusan Pembelian

b. Predictors: (Constant), Word of Mouth, Ekuitas Merek Sumber: hasil pengolahan data dengan SPSS versi 21

Berdasarkan tabel 5 di atas diperoleh Fhitung sebesar 47,894 > Ftabel dengan $(0,05 ; 2$ vs 49) dengan df =n-k-1 (52-2-1=49) sebesar 3,19 atau tingkat signifikansi $0,000 \leq \alpha 0,05$ maka Ho ditolak, artinya ekuitas merek dan word of mouth berpengaruh positif dan signifikan terhadap keputusan pembelian smartphone Oppo pada mahasiswa STIE Sultan Agung.

\section{b) Uji Parsial (Uji t)}

Pengujian ini dilakukan secara parsial yang dilakukan untuk menentukan diterima atau ditolaknya hipotesis. Pengujian hipotesis dilakukan untuk mengetahui apakah variabel ekuitas merek dan word of mouth yang diuji berpengaruh terhadap keputusan pembelian. Jika $t_{\text {hitung }}>t_{\text {tabel }}$ atau signifikansi $\leq 0,05$, maka $\mathrm{H}_{0}$ ditolak.

\section{Tabel 6}

\section{Perkiraan Nilai thitung}


Coefficients

\begin{tabular}{|rl|r|r|}
\hline & & & \\
\hline & & $\mathrm{t}$ & \multicolumn{1}{|c|}{ Sig. } \\
\hline 1 & (Constant) & 1.519 & .135 \\
& Ekuitas Merek & $\mathbf{5 . 4 4 5}$ & $\mathbf{. 0 0 0}$ \\
& Word of Mouth & $\mathbf{2 . 7 5 1}$ & $\mathbf{. 0 0 8}$ \\
\hline
\end{tabular}

a. Dependent Variable: Keputusan Pembelian Sumber: hasil pengolahan data dengan SPSS versi 21 Berdasarkan tabel 5 diperoleh diperoleh nilai thitung pada variable ekuitas merek sebesar 5,445 > ttabel -dengan df = n-k-1 (52-2-1 = 49) sebesar 2,00 atau taraf signifikansi $0,000 \leq \alpha 0,05$, maka $\mathrm{H} 0$ ditolak, artinya ekuitas merek berpengaruh positif dan signifikansi terhadap keputusan pembelian smartphone Oppo pada mahasiswa STIE Sultan Agung.

Kemudian nilai thitung pada variabel word of mouth sebesar 2,751> ttabel dengan df $=\mathrm{n}-\mathrm{k}-1$ (52$2-1=49)$ sebesar 2,00 atau taraf signifikansi 0,008 $\leq$ $\alpha 0,05$, maka H0 ditolak, artinya word of mouth berpengaruh positif dan siginifikansi terhadap keputusan pembelian smartphone Oppo pada mahasiswa STIE Sultan Agung.

\section{Evaluasi}

\section{Ekuitas Merek Pada Smartphone Oppo}

Dimensi asosiasi merek, fitur yang canggih smartphone Oppo memperoleh nilai rata-rata 3,44. Sebaiknya, perusahaan Oppo dapat terus berinovasi dalam segi fitur produk agar mendapat perhatian dari konsumen, kemudian memberikan kemudahan kepada konsumen dalam pengoperasian fitur-fitur yang canggih yang ada pada produk smartphone Oppo. Untuk dimensi loyalitas merek, pada indikator komitmen untuk menggunakan smartphone Oppo dibandingkan dengan merek lain memperoleh nilai rata-rata 3,71. Sebaiknya, pelanggan merasakan bahwa produk yang ditawarkan sesuai dengan peforma yang tepat, desain yang tepat, fitur yang tepat dan kualitas harga yang tepat. Sehingga konsumen terpuaskan dan komitmen terhadap smartphone Oppo dan mereka percaya akan produk bahkan membayar lebih pada produk tersebut dibandingkan dengan merek lain.

Pada indikator pilihan utama konsumen dalam memilih smartphone Oppo memperoleh nilai ratarata 3,73. Cara mengatasinya, Oppo sebaiknya melakukan inovasi mengenai kualitas fitur-fitur yang paling diinginkan masyarakat dalam sebuah smartphone yang banyak dicari yaitu kamera. Sehingga dengan ditingkatkan kualitas fitur kamera terutama kamera depan menjadi pilihan utama konsumen untuk melakukan selfie. Pada indikator rekomendasi kepada orang lain memperoleh nilai rata-rata 3,87. Sebaiknya, demi kepuasan konsumen smartphone Oppo tetap menerapkan kamera depan dan juga belakang yang super canggih dan spesifikasinya setara dengan smartphone kelas high end sehingga mendorong tersebarnya rekomendasi dari mulut ke mulut yang positif, perlu ditingkatkan agar konsumen terus merasa puas dengan membeli maupun menggunakan produk.

\section{Word of Mouth Pada Smartphone Oppo}

Dimensi talkers, pada indikator pengaruh seseorang dalam keputusan pembelian konsumen memperoleh nilai rata-rata 3,71. Untuk mengatasi hal ini, Oppo meningkatkan promosi produk melalui teman dan kerabat konsumen sehingga informasi yang disampaikan diketahui oleh konsumen kemudian konsumen mengetahui mengenai informasi produk smartphone Oppo dari orang-orang yang dapat dipercaya. Untuk dimensi tools pada indikator brosur smartphone Oppo memperoleh nilai rata-rata 3,35. Untuk mengatasi hal ini, brosur yang dibagikan kepada konsumen tepat sasaran dan menginformasikan secara detail mengenai spesifikasi smartphone Oppo terbaru dalam jumlah yang banyak dan penyebaran brosur tidak hanya dilakukan di toko dan gerai saja tetapi di perkantoran dan pedesaan agar konsumen mengerti dan mengetahui produk smartphone Oppo.

Pada indikator iklan smartphone Oppo yang dibicarakan konsumen memperoleh nilai rata-rata 3,29. Sebaiknya, iklan yang sangat gencar dan menarik di jam prime time merupakan solusi untuk membangun kesan yang baik kepada konsumen sehingga konsumen dapat membicarakan smartphone Oppo melaui iklan yang dilihatnya. Pada indikator media sosial smartphone Oppo yang dibicarakan konsumen memperoleh nilai rata-rata 3,63. Untuk mengatasi hal ini, ketersediaan media sosial smartphone Oppo sebagai tempat untuk memudahkan konsumen menceritakan pengalamannya tentang produk smartphone Oppo. Perusahaan harus membuat komunitas online khusus pengguna smartphone Oppo, sehingga konsumen dapat membicarakan pengalamannya tentang produk di komunitas online tersebut.

Dimensi taking part pada indikator diskon yang diberikan oleh smartphone Oppo memperoleh nilai rata-rata 3,73 . Untuk mengatasi hal ini diskon harus lebih menarik lagi karena diskon sangat mempengaruhi keputusan konsumen untuk membeli Oppo smartphone. Selanjutnya untuk dimensi tracking pada indikator Service Center Oppo memperoleh nilai rata-rata 3,65. Sebaiknya, Oppo Service Center yang menyediakan Pick Up \& Delivery Service, yaitu penjemputan perangkat Oppo yang mengalami masalah kerusakan dapat menanganinya dengan baik agar dapat sesuai dengan harapan konsumen. Pada indikator customer service Oppo memperoleh nilai rata-rata 3,79. Sebaiknya, perusahaan dapat menangani dalam menjelaskan produk secara detail sebagai tempat kritik dan saran konsumen melalui 0018038516776.

\section{Keputusan Pembelian Pada Smartphone Oppo}

Dimensi pengenalan masalah, pada indikator kebutuhan konsumen dalam membeli smartphone Oppo memperoleh nilai rata-rata 3,96. Untuk mengatasi hal ini, pihak Oppo memudahkan 
konsumen mendapatkan informasi dengan menyediakan jenis-jenis produk yang berkualitas. Kesempatan ini sebaiknya dimanfaatkan smartphone Oppo untuk menciptakan smartphone yang dapat memenuhi kebutuhan konsumen. Dimensi evaluasi alternatif, pada indikator evaluasi produk smartphone Oppo yang ada dipasaran memperoleh nilai rata-rata 3,96. Untuk mengatasi hal tersebut, konsumen dapat mengevaluasi jenis jenis produk berkualitas dengan kebijakan harga yang disediakan oleh Oppo yang ada dipasaran sesuai apa yang di inginkan oleh konsumen. Pada indikator desain yang cermat smartphone Oppo memperoleh nilai rata-rata 3,40. Untuk mengatasi hal ini, smartphone Oppo berinovasi dalam menghadirkan produk mengedepankan teknologi yang cerdas dengan desain yang cermat dan unik, sehingga mengedepankan spesifikasi mumpuni yang dapat membantu aktivitas konsumen.

Dimensi keputusan pembelian konsumen, pada indikator promosi yang diberikan oleh smartphone Oppo menguntungkan konsumen memperoleh nilai rata-rata 3,96. Untuk mengatasi hal ini, Oppo melakukan promosi yang lebih menarik sehingga konsumen merasakan manfaat dan kentungan yang diperoleh dari strategi perusahaan. Kemudian dimensi perilaku setelah pembelian, pada indikator konsumen membeli kembali produk smartphone Oppo memperoleh nilai rata-rata 3,75. Sebaiknya hal ini dapat diperbaiki dengan cara menyediakan merek produk yang memiliki kualitas produk yang terjamin dan memberikan daya tarik yang diinginkan oleh konsumen. Pada indikator varian terbaru smartphone Oppo memperoleh nilai rata-rata 3,69. Sebaiknya, Oppo memberitahukan kepada konsumen varian terbaru yang ditawarkan untuk melakukan pembelian tipe terbaru, dan untuk mengganti tipe smartphone Oppo lama yang konsumen miliki.

\section{KESIMPULAN DAN SARAN}

\section{Kesimpulan}

a. Hasil analisis deskriptif kualitatif tentang ekuitas merek diperoleh rata-rata jawaban keseluruhan sebesar 3,92 dengan kriteria jawaban setuju. Nilai rata-rata tertinggi sebesar 4,25 pada dimensi asosiasi merek dengan indikator manfaat smartphone Oppo bagi mahasiswa. Sedangkan untuk nilai rata-rata terendah 3,44 pada dimensi asosiasi merek dengan indikator fitur smartphone Oppo yang canggih.

b. Hasil analisis deskriptif kualitatif tentang word of mouth diperoleh rata-rata jawaban keseluruhan sebesar 3,80 dengan kriteria jawaban setuju. Nilai rata-rata yang tertinggi sebesar 4,12 pada dimensi topics dengan indikator lokasi yang mudah dijangkau oleh konsumen. Nilai rata-rata terendah sebesar 3,29 pada dimensi tools dengan indikator iklan smartphone Oppo yang dibicarakan oleh konsumen.

c. Hasil analisis deskriptif kualitatif tentang keputusan pembelian diperoleh rata-rata jawaban keseluruhan sebesar 3,98 dengan kriteria jawaban setuju. Nilai rata-rata tertinggi sebesar diperoleh 4,25 pada dimensi keputusan pembelian konsumen dengan indikator keputusan konsumen tentang pelayanan yang memuaskan diberikan smartphone Oppo. Sedangkan nilai rata-rata terendah adalah 3,40 pada dimensi evaluasi alternatif dengan indikator desain smartphone Oppo yang cermat.

d. Hasil analisis regresi linier berganda diperoleh persamaan $\hat{\mathrm{Y}}=8,177+0,724 \mathrm{X} 1+0,255 \mathrm{X} 2$, artinya terdapat pengaruh yang positif antara ekuitas merek (X1) dan word of mouth (X2) terhadap keputusan pembelian (Y) smartphone Oppo pada mahasiswa STIE Sultan Agung.

e. Hasil nilai analisis korelasi diperoleh nilai $r$ sebesar sebesar 0,813 yang berarti terdapat hubungan yang sangat kuat dan positif antara variabel ekuitas merek (X1) dan word of mouth (X2) dengan keputusan pembelian (Y) smartphone Oppo pada mahasiswa STIE Sultan Agung. Kemudian diperoleh nilai koefisien determinasi ( $\mathrm{R}$ Square) sebesar 0,662, artinya keputusan pembelian (Y) pada smartphone Oppo sebesar $66,2 \%$ dipengaruhi oleh ekuitas merek (X1) dan word of mouth (X2), selebihnya 33,8\% dipengaruhi oleh variabel-variabel lain yang tidak dijelaskan pada penelitian ini seperti iklan, fitur, harga, promosi, kualitas pelayanan dan sebagainya.

f. Hasil pengujian hipotesis seacara simultan dengan uji $\mathrm{F}$, dapat diketahui bahwa terdapat pengaruh yang positif dan signifikan antara variabel ekuitas merek dan word of mouth terhadap keputusan pembelian, dimana nilai Fhitung sebesar 47,894 > Ftabel dengan $(0,05,2$ vs 49) dengan $\mathrm{df}=\mathrm{n}-\mathrm{k}-1(52-2-1=49)$ sebesar 3,19 atau dengan tingkat signifikansi $0,000 \leq \alpha$ 0,05 maka Ho ditolak, artinya ekuitas merek dan word of mouth berpengaruh positif dan signifikan terhadap keputusan pembelian smartphone Oppo pada mahasiswa STIE Sultan Agung.

g. Hasil pengujian hipotesis secara parsial dengan uji t, dapat diketahui bahwa terdapat pengaruh yang positif dan signifikan antara variabel ekuitas merek dan word of mouth terhadap keputusan pembelian, dimana nilai didapat thitung pada variabel X1 $\neg$ (ekuitas merek) sebesar 5,445 > ttabel dengan $=\mathrm{n}-\mathrm{k}-1(52-2-1=49)$ sebesar 2,00 atau taraf siginifikan $0,000 \leq \alpha \quad 0,05$ maka Ho ditolak, artinya ekuitas merek berpengaruh positif dan signifikan terhadap keputusan pembelian smartphone Oppo pada mahasiswa STIE Sultan Agung. Kemudian nilai thitung pada variabel X2 (word of mouth) sebesar 2,751 > ttabel dengan dengan $=\mathrm{n}-\mathrm{k}-1(52-2-1=49)$ sebesar 2,00 atau taraf signifikan $0,008 \leq \alpha 0,05$ maka Ho ditolak, artinya word of mouth berpengaruh positif dan signifikan terhadap keputusan pembelian smartphone Oppo pada mahasiswa STIE Sultan Agung. 


\section{Saran}

a. Untuk meningkatkan ekuitas merek pada smartphone Oppo, perlu dilakukan inovasi fitur yang canggih yang sesuai dengan keinginan konsumen seperti fitur selfie dengan kualitas kamera yang sangat bagus dan prima serta resolusi kamera yang cukup besar untuk mendapatkan hasil selfie yang berkualitas.

b. Untuk mempertahankan word of mouth pada smartphone Oppo, maka penyebaran informasi atau promosi melalui iklan sebaiknya di jam prime time dengan konsep iklan yang lebih

\section{E. DAFTAR PUSTAKA}

Berga, Devi Liana dan Devilia Sari. Pengaruh Kualitas Produk, Harga dan Word of Mouth terhadap Proses Keputusan Pembelian (Studi pada Konsumen Martabak Jayaraga Jalan Terusan Buahbatu Bandung). Bandung. Universitas Telkom. Skripsi.

Hasan, Ali. 2010. Marketing dari Mulut ke Mulut (Word of Mouth Marketing). Yogyakarta: Media Pressindo.

Hasan, Ali. 2013. Marketing dan Kasus-Kasus Pilihan. Cetakan Kedua, Jakarta: Center for Academic Publishing Service.

Kotler, Philip dan Gary Armstrong. 2008. Prinsipprinsip Pemasaran. Edisi 12. Jilid 1 dan 2. Jakarta: Erlangga.

Kotler, Philip dan Kevin Lane Keller. 2008. Manajemen Pemasaran. Edisi 12. Jilid 1. Jakarta: Indeks.

Kotler, Philip dan Kevin Lane Keller. 2009. Manajemen Pemasaran. Edisi 13. Jilid 1 dan 2. Jakarta: Erlangga.

Lupiyoadi, Rambat dan Hamdani. 2006 Manajemen Pemasaran Jasa. Edisi 2. Jakarta: Salemba Empat.

Mowen, Jhon C dan Michael Minor. 2002. Perilaku Konsumen. Edisi 5. Jilid 2. Jakarta: Erlangga.

Sernovitz, Andi. 2009. Word of Mouth Marketing: How Smart Companies Get People Talking. New York. Kaplan.

Setiadi, Nugraha J. 2008. Perilaku Konsumen. Jakarta: Kencana.

Tjiptono, Fandy. 2011. Manajemen dan Strategi Merek. Yogyakarta: Andi menarik agar pengguna produk smartphone Oppo semakin bertambah.

c. Untuk mempertahankan dan meningkatkan keputusan pembelian konsumen pada smartphone Oppo dengan melakukan inovasi dalam menghadirkan desain yang cermat dan mengedepankan spesifikasi teknologi yang cerdas agar mendapatkan perhatian dari konsumen. 